\title{
特集 [人間科学の方法について
}

\section{序 人間科学とは何か}

\section{永井}

「人間科学」についての確定した定義は，まだない。 今後もおそらく，簡単には決まらないであろう。しか し, Aristoteles がかつて第一哲学 (形而上学) に与えた 語を流用することが許されるならば，この科学が「求め られている」科学であることは間違いない。

人間を規定する条件は極めて多様であるが，それらを 大まかに区分するなら，自然的, 文化的, 社会的, 歴史 的の諸条件を数えることができよう。しかし，これらの 条件のどの一つをとっても，それがさらに果てしなく分 岐・細分化し，ほとんど見究めもつかない様相を呈す る。かくして, 人間は複雑多様な諸条件によって規定さ れる特異な複合体である。最近 2,30 年の自然, 人文, 社会諸科学の目覚ましい発展によって，そうした条件の 微視的機構は次第に明らかになったが，にもかかわら ず，研究が進めば進むほどかえって分らない問題が続出 してきていることも，否定できない実情のようである。

たとえば, 生物科学のなかで最も進境の著しい遺伝学 では, 分子生物学的方法によって画期的な成果がもたら されたが，同時に多くの難問が浮上し，その解決は必ず しも容易でないとされている。しかしそれとともに, 得 られた理論的結果が活発に技術化され，人間に吉凶両様 の工学的影響を及ぼしつつあることもまた，見逃すこと のできない事実なのである。

かつてはいわゆる哲学的人間学が，人間の全体的本質 構造を解明でさると主張したこともあったが, 今日では， 諸個別科学の発展によって，そうした多分に規範的な発 想・議論は，ほとんど色褪せたものとなってしまった。 しかし，個別科学は，人間の極微的諸条件を析出しはす るが，それによって全体としての人間あるいは全体的人 間の具体相を呈示することはできない。一方において人 間の微視的探究はますます進むが，同時に他方ではわれ われは，人間を全体として理解しょらとする，断ちがた い要求をもっている。ここに, 一つの総合科学あるいは 統一科学として，人間科学の要請される理由があるので あろら。のみならず, 研究の微視的細分化が進めば進む ほど, 逆に総合・統一への要請は高まるといってよい。

\footnotetext{
* 筑波大学・哲学
}

\section{博*}

しかし問題はまさに, その「総合」「統一」の理念と方 法は何か，果してそれは可能であるか，という点にあ る。

その場合, 総合や統一をあせるあまり, いわゆる還元 主義による統一を企てたり (unified science), 個別科学 の成立原理となっている universal を階層的に配列し， その間の isomorphismを形式的・システム論的に整理し てみせたところで，見た目には美しいかも知れないが， 求める人間科学の現実的構築に役だつとは思えない。そ らいう議論では, Homo sapiens の実質的かつ総合的考 察にほとんどかかわることができないからである。全体 的人間の総合科学的考察ということは, 実際には気の遠 くなるよらなむつかしい課題であることを筧悟しなくて はなるまい。個別科学の研究の現場にあってそれぞれ難 問をかかえ, それの打開に苦慮している科学者にとって は，そらいう提言は，おそらく空虚な掛声としてしかひ びかないであろう。

それにもかかわらず, 今日の生物科学は, 生物工学と 提携して個人としての人間ばかりでなく，人類全体の命 運を左右するほどの実力を保持するに至った。その点で は, 物理科学に決して劣ることはないといっても過言で はない。末解決・未知の問題は山積しているし, 一般に 科学には最終的完成はないとしても, 最近の四半世紀間 に達成された業績でさえ，すでに人類の未来を妿かすに 足る質と量を具えていることを忘れてはならない。だか らもし，人間にかかわる個別科学の分析的傾向がますま す進み，その成果が人間科学の全体理念のレヴェルにフ イードバックされて有機的・合目的的に制御されること がなければ，人間に関する科学的知識はいたずらに放散 し，かえって人間解体の傾向に拍車をかけるだけに終っ てしまらのが拈ちであろう。それでは「人間科学は何の ために?」といった，抜きがたい不信感を誘発すること になる。森の中にあって森を見ず，木原論文の比喻を借 りるならば「モナ・リザの絵を電子顕微鏡で観察してい る」といった弊に陥らなければ幸いである。

人間科学は総合科学であり, その必要性の高まってい ることは確かであるが，それには上述のよらなディレン 
マが内藏されており,このアポリアは, 単に理論的には 解くことのできないものではなかららか。特にその方法 論は重要であるが，それを理論的に詮議しても，稔り少 ないであ万う。私見によれば，方法論は実践的性格をも たざるを得ないし，またもつべきであると思う。

まず, 個別科学の㼋究者は, 自分の研究が直接人間の 問題に関与すると否とにかかわりなく, その表門研究を 深め払張し, 未解決問題の打開注挺身寸ると同時に, 研 究は何のために, という目的意識をつ权堅持していな ければならない(沢田論文参照)。個別科学の研究法は, 対象と条件, 研究者の個性, 置かれた状況等々によって 異なる。巨視的・抽象的には，方法の特徽のいくつかを 並べて提示することはできようが，微視的・現実的に は, 極言すれば千差万別というのが本当のところであろ う。

それにもかかわらず，個々の科学者の研究は「何のた めに」と問らならば，それは実践的な設問となり，答は 簡単明膫であろら。なぜならば，科学は科学そのものの ためにではなく, 個々の人間の幸福, さらに人類の平和 と繁栄のためにこそ研究さるべきものだからである。仮 りにそれ以外のもののために研究されることがあってる 「究極的には」上記の目的のために，でなければならな い。そうでなければ, 一般浪科学は, そして特に人間科 学は, むしろ無きに如くはないといってもよいであろ う。それをそうでなくするものは，全体的人間の理念を 現実化しようとする, 研究者の善意志の涪かにない。こ の確認, いわゆる consensus gentiumを取りつけること は, 必ずしも困難ではないと思う。
科学者は, 現実には, 科学者一般としてではなく, 必 ずある個別科学の専門研究者として事存する。それ以外 に, 科学者の在りようはない。してみれば, 科学者にと っては，その專門を通して人䦌科学に贡献するほかに道 はないというべきであろう。そのとき，彼の研究が本当 に実のある研究となるためには，上述のようなコンセン サスへの積極的な関与が必須の条件となる。そしてその 条件を満たすことは，すぐれて尖践的な邀扑なのであ る。

人間科学の方法は, 実のところ, 方法としてあからさ まに, あるいは客锶的に定式化できるものではなく, む しろ实践的格率として, 個別科学の実地の研究を筧く, いわば隠れた統制原理の機能を果たすべきものと考兄ら れないだろらか。自然, 人文, 社会のすへてての分野の学 者または科学者は，それぞれの研究を通して，全体的人 間の理念, 個人の祩福, 人類の平和と繁喿に奉仕し, い わば「見光ざる連带」を結成すべく義務づけられている といえないだろらか。このことが認められるならば，そ の連带のもとに初めて, 個々の研究も趾活され, 研究の 喜びも実感されるといらものである。かくして，どんな 分野の研究者も, その見光ざる連带の一員として, 何ら かの協力を行らことができるようになるであうう。

本号の特集テーマは, 昭和53 (1978) 年, 緗集委員 会が行ったアンケート調查に対して寄せられた会只の さまざまの回答結果を改めて梌討し，現下の科学基礎 諭に与えられた基本的課題は何か，について颜議した 結果採択された。御多忙のなか, 寄稿していただいた 執筆者に対して, 深䍘の謝意を表します。 